\title{
Spreading (dis)trust in Fiji? Exploring COVID-19 misinformation on Facebook forums
}

\begin{abstract}
The COVID-19 pandemic has caused significant challenges for the health system across the globe and fueled the surge of numerous rumours, hoaxes, and misinformation regarding outcomes, prevention and cure of the virus. The COVID-19 pandemic has also had severe political, economic and societal effects and affected media and communication systems in unprecedented ways. While traditional journalism has tried to adapt to the rapidly evolving situation, alternative news media on the internet have given the events an ideological spin. These voices have been criticised for furthering societal confusion and spreading potentially dangerous 'fake news' or conspiracy theories via social media and other online channels. The impact of the disease and the lack of information associated with it have allowed medical misinformation to rapidly surface and propagate on various social media platforms. Previous studies have highlighted a similar trend during recent public health emergencies, mainly the Ebola and Zika outbreaks. Such a phenomenon is alarming on both individual and public health levels to the extent that governments are realising the gravity and attempting to limit its effects. This article offers a unique perspective because it provides data-driven qualitative insights into Fijian Facebook posts related to infectious disease outbreaks. This study aims to understand public views and opinions on Fijian social media during the height of the pandemic in 2020 and to outline potential implications for health information.
\end{abstract}

Keywords: case studies, COVID-19, Facebook, fake news, Fiji, internet, misinformation, Pacific studies, social media

\section{ROMITESH KANT}

La Trobe University, Melbourne, Australia

\section{RUFINO VAREA}

The University of the South Pacific, Suva, Fiji

$\mathrm{T}$

HE IMPACT of the global COVID-19 pandemic and gaps in medical knowledge about the virus have allowed medical misinformation to surface rapidly and propagate on various social media platforms. According to the World Health Organisation (WHO), at the time of writing, the pandemic had led to more than 128 million confirmed cases and more than 2.9 million deaths around the world. In the Pacific, Fiji has been one of 11 countries with confirmed 
cases of COVID-19 and has been one of the hardest hit by the pandemic.

Traditionally, print media, television and radio have been the primary transmitters of public health information from government and clinical agencies to people and play a significant role in risk intensification and mitigation. With the rise of the participatory web and social media (Web 2.0) and a resulting increase in user-generated content, the public potentially plays a more prominent role in all stages of knowledge translation, including information generation, filtering, and amplification.

While misinformation involves inadvertently sharing false information without intent to cause harm, disinformation involves incorrect information knowingly being created and transmitted to cause damage (Wardle \& Derakhshan, 2017). 'Fake news' is the term that has received the most attention; but it is arguably problematic in terms of definitional rigour. Lazer et al. (2018) depict it as fictitious, made-up information that imitates news media content, but this does not capture the complexity of the phenomenon, which can include both satire and information created deliberately to mislead as a means to achieve a political or another goal (Wardle, 2017). The term has taken on various meanings, including a description of any statement that is not liked or agreed with by the reader (Wang, McKee, Torbica, \& Stuckler, 2019).

Social media platforms like YouTube and Facebook have been identified as significant online spaces for dissemination of conspiracy beliefs and misinformation on medical and other topics (Bora, Das, Barman, \& Borah, 2018; Buchanan \& Beckett, 2014; Chaslot, 2017; Li, Bailey, Huynh, \& Chan, 2020). There are studies of Twitter that suggest that it is a conduit for similar misinformation and conspiracy theories (Broniatowski, et al., 2018; Kouzy, et al., 2020; OrtizMartínez \& Jiménez-Arcia, 2017). Although social media misinformation is both pervasive and widespread, its effects are hard to quantify and it is unclear which groups are most susceptible to its influence (Wang, McKee, Torbica, \& Stuckler, 2019). As the internet provides immense opportunities for transmission, it also lowers the cost of generating and disseminating information, thus allowing misinformation and sensationalised stories to propagate. This has caused a series of studies of information diffusion (Serrano, Iglesias, \& Garijo, 2015), rumour spreading (He, Cai, \& Wang, 2015) and consequent behavioural changes (Salathé \& Khandelwal, 2011; Wakamiya, Kawai, \& Aramaki, 2016).

Social media platforms have been rolling out new initiatives, including advisories (Twitter) and removing certain anti-vaccination content from search results (Pinterest) and recommendation engines (YouTube) (Seyoum, 2019).

This article investigates the diffusion of different kinds of (mis)information shared on and through Facebook during the first wave of the COVID-19 outbreak in Fiji in 2020. We thus use the term disinformation as shorthand for unreliable information in several forms - all potentially harmful — including false news, 
click-bait, propaganda, conspiracy theories and unverified rumours. We used a set of keywords related to the epidemic and limited the search to posts in Fijian Facebook groups. This article investigates the prevalence of non-reliable information by analysing the posts in Fijian Facebook groups and the domain of URLs included in such posts. To this aim, we specified keywords related to three different controversial topics that trended from February to June of 2020, all related to the novel coronavirus: the apparent correlation between; COVID-19 and religion; the virus and fifth generation $(5 \mathrm{G})$ technology and rumours about the artificial origin of the virus.

\section{Fiji's COVID-19 timeline (2020)}

COVID-19 emerged in Wuhan, China in early December 2019, was brought to the notice of the authorities in late December/early January 2020 and, after investigation, was declared an emergency in the third week of January 2020. The WHO declared it a Public Health Emergency of International Concern (PHEIC) on January 31, 2020 and finally a pandemic on 11 March 2020.

The COVID-19 pandemic was confirmed to have reached Oceania on 25 January 2020, with the first confirmed case reported in Melbourne, Victoria, Australia (Australian Department of Health, 2020). It has since spread elsewhere in the region (Australia, Fiji, French Polynesia, Guam, New Caledonia, New Zealand, Northern Mariana Islands and Papua New Guinea), although many small Pacific Island nations have thus far avoided the outbreak by closing their international borders (World Health Organisation, 2020).

Many other Pacific Islands Countries (PICs) are officially free of COVID-19 due to the strict restrictions imposed to prevent the spreading of COVID-19. Some island nations have declared a state of emergency, lasting months. Air travel and commercial flights have practically ceased (ABC News, 2020). As of August 24 that year, 10 Pacific Islands Countries had yet to report a case: Kiribati, Marshall Islands, the Federated States of Micronesia, Nauru, Palau, Samoa, the Solomon Islands, Tonga, and Vanuatu.

In late January 2020, the Fijian Government began preparing for COVID-19, working closely with the World Health Organisation, New Zealand and Australia to build its domestic capacity to identify, trace and contain potential cases and procure additional ventilators medical masks and other critical items (Rabonu, 2020). In early February, Fiji began implementing and gradually tightening restrictions on travellers who had spent time in existing hotspots.

Fiji confirmed its first case of the coronavirus on March 19 and opened 32 fever and testing clinics to contain the spread of the virus. The Ministry of Health deployed contact tracing teams to track and monitor cases. On March 25, Fiji grounded commercial international flights and sealed its borders. The Fijian Government locked down Lautoka and Suva, where cases were confirmed, 
banned social gatherings and imposed a nationwide curfew. Between March 19 and April 20, Fiji confirmed six clusters and 18 cases of COVID-19, but community transmission did not occur.

By 19 July 2021, Fiji had recorded 17,514 cases of COVID-19 with 98 deaths (Ministry of Health and Medical Services, 2021). During the first wave of the outbreak, Fiji recorded 70 cases and two deaths (48 cases part of the border quarantine facilities, including the two deaths). Since July 2020, Fiji has only recorded cases from managed quarantine facilities at the border as repatriation flights continue to bring citizens home (Ministry of Health and Medical Services, 2021). The Ministry of Health's Fiji Center for Disease Control has conducted 268227 COVID-19 laboratory tests since local testing began in March 2020, of which 225,366 were between 19 April-19 July 2021, during the second wave of the outbreak (Ministry of Health and Medical Services, 2021).

\section{Fiji's digital landscape and its impact}

Over the past decade, Fiji has been at the forefront of an ICT revolution in the Pacific fueled by liberalisation of the mobile telecommunications industry, leading to improvements in internet connectivity and low costs for access (Brimacombe, Kant, Finau, Tarai, \& Titifanue, 2018).

As at February 2021, Fiji had 634,100 internet users with 1.25 million active mobile phone SIM registrations (138.6 percent of the population). Of these mobile users, 88.7 percent have $3 \mathrm{G}$ and $4 \mathrm{G}$ internet connections (Kemp, 2021). The proliferation of mobile phones means that the internet, previously limited to the urban centres, has become more widely accessible through mobile broadband, with $3 \mathrm{G}$ connectivity in the country since 2008 .

Facebook and Facebook Messenger are the most used social media platforms in Fiji with 570,000 and 460,000 active users, followed by LinkedIn (160,000 users), Instagram (140,000 users) and Twitter (14,800 users) (Kemp, 2021). Mobile phones account for 99.3 percent of social media use. Traditional media — especially radio and television—are still the primary information sources for most Fijians while Facebook is the third most popular source of information, surpassing newspapers (Kant, Jorari, \& Cain, 2021, p. 16).

Fijians and Pacific Islanders are becoming avid consumers of ICT technologies. In many Pacific Islands, mobile phone technology has become pervasive, especially in urban centres. With the rapid ICT development and innovations taking place, there is enormous potential for exponential increases in the use of social media in the Pacific. Social media has come to play a significant role in developing political discourse and activism within the Pacific region. The rise of alternative forms of information dissemination through social media provides a platform for discussion and dissemination of information relating to issues censored by traditional media (Finau et al., 2014; Tarai et al., 2015; Titifanue et 
al., 2015; Titifanue, Kant, \& Finau, 2020). Through social media, citizens have also been able to criticise government policies and, to some extent, hold government officials accountable (Cave, 2012; Logan, 2012). Digital technologies also provided a space for Pacific Islanders' voices to be heard in times of natural disasters as witnessed during Tropical Cyclone Pam in Vanuatu in 2015 and Tropical Cyclone Winston in 2016 in Fiji (Finau, et al., 2018; Spyksma, 2017).

While social media in the Pacific is opening spaces for transparency and accountability, it is increasingly being used as a platform to spread rumours, misinformation and fake news. The harmful effects of the use of social media as a tool to spread misinformation were seen during the 2019 measles outbreak in Samoa. Within two months, 5520 cases had been reported and 79 people, mostly children, had died. (Hooper, 2020). Social media are heavily used in Samoa and became the main channel for the anti-vaxxers' opinions and exhortations. Prominent among these were well-known and highly regarded traditional healers. While the Samoan Government attempted to bring the measles outbreak under control by mounting a nationwide vaccination campaign, they had to deal with the undermining influence of the anti-vaccination campaigners on social media (Hooper, 2020).

\section{Method}

A case study approach was used that traditionally consists of studying a particular phenomenon in its real-life context. This study was pragmatic in that the methods for data collection could provide answers to the research questions.

Our analysis used a grounded theory approach. We collected and analysed Facebook interaction data without a predefined theory, allowing concepts and ideas to emerge naturally (Glaser \& Strauss, 1967). A strength of this approach is that it enables the researcher to study human interaction and behaviour within its social context (Schreiber \& Stern, 2001). This study shows that the Facebook community serves as the larger social context, and the conversations and interactions on Facebook forums are the studied behaviour.

Social media qualitative research methods can be described in three ways: active analysis, passive analysis, and research self-identification (Franz, Marsh, Chen, \& Teo, 2019). Active analysis on Facebook involves the participation of research members in communication with Facebook participants. Passive analysis on Facebook involves studying information patterns observed on Facebook or the interactions between users in existing Facebook groups. Finally, research self-identification is when researchers use Facebook as a research recruitment tool to gather participants for web-based interviews, focus groups, or surveys (Franz, Marsh, Chen, \& Teo, 2019). This study is based on passive analysis using data sourced from two popular Facebook groups in Fiji. These Facebook groups were Chat (Fiji), and Fijians for Safe and Prosperous Fiji (formerly Stop 
5 G Fiji). Chat (Fiji) was chosen due to its popularity, as it had more than 250,000 members when the data was acquired for this research. In contrast, Fijians for Safe and Prosperous Fiji was chosen as it was initially set up as an 'anti-5G' group for Fiji on 6 April 2020, but later changed its name to Fijians for Safe and Prosperous Fiji. It had 14,000 members at the time of the data acquisition for this study. The group is currently known as Current Affairs Fiji.

To find out what types of misinformation were prominent during the pandemic on Fiji's social media, we used the search function within these two Facebook groups, using the terms: Coronavirus, COVID-19/COVID19, Corona, virus, $5 \mathrm{G}$. The number of public interactions was collected for each relevant post and included the online networks' public engagement feature tools such as likes, reactions, comments and shares (Figure 1).

A total of 184 posts was collected from these two groups, with 123 posts from Chat (Fiji) (https://www.facebook.com/groups/LETSTALK11/about) and 61 from Stop 5G in Fiji (https://www.facebook.com/groups/2667187216881576).

The content was categorised according to its source (i.e., who initiated the post; host generated vs user-generated). The content was then analysed for distinct themes and concepts and their primary functions (Figure 2). One researcher began this process by reading through each post on the wall and the post's responses. Each post was copied and pasted into a spreadsheet with the corresponding responses.

\section{Results}

Misinformation took a variety of forms across Fijian social media, especially toward the beginning of the pandemic in March 2020. It was found that the content of posts on both Facebook forums that were analysed were made up largely of opinion pieces (30 percent), most of which were genuine content about the issues surrounding the global COVID-19 pandemic (Figure 2). Findings also showed

\section{Figure 1: Posts made by members of two Fiji Facebook forums}

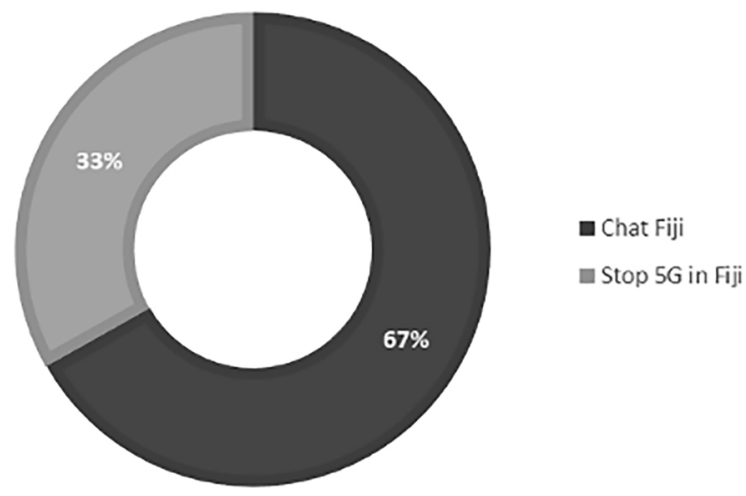

Note: Number of posts made by members of two Facebook forums; Chat Fiji and Stop 5G in Fiji 


\section{Figure 2: Information proportions on Chat Fiji, Stop 5G}

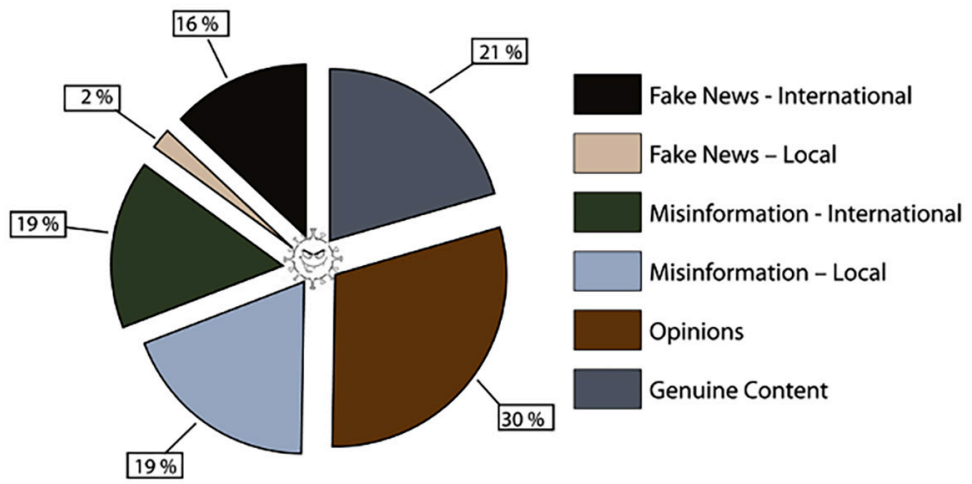

Note: Proportion of information on Chat Fiji and Stop 5G in Fiji, categorised according to local and international fake news and misinformation, personal opinions and genuine content.

that international fake news and misinformation featured strongly on both fora. (16 percent and 19 percent, respectively) to support claims that were in contradiction to public health advisories by the government and trusted health organisations like WHO and the CDC. Local fake new and misinformation formed a minority of the forum content, with little traction (21 percent collectively) and were mainly faith-based opinion pieces. Since the writing of this article, it has been observed that the use of misinformation and conspiracy theories that downplay the seriousness of the COVID-19 pandemic and the importance of the vaccination have increased. Many of the prior claims made by online members of the Facebook group forums were strengthened with the widespread use of herbal remedies like Scaevola taccada (also known as beach cabbage or sea lettuce) and traditional treatments such as steam therapy for minor COVID-19 symptoms Additionally, some articles have been used to argue the benefits of ivermectin and hydrochloroquine for the treatment of COVID-19 positive patients in Fiji (Figure 3).

The thematic analysis around conspiracy theories focused on local types and sources of information under the following themes and sub-themes: Politicisation of COVID-19; online vilification of COVID-19 patients; creation of the Stop 5G in Fiji Facebook Groups Dead birds, 5G and COVID-19; Prevalence of international conspiracy theories on Fijian Facebook forums; Conspiracy theory about the link between 5G technology and coronavirus; Bill Gates and COVID-19 and the fabrication of coronavirus in a Chinese laboratory.

\section{Local types and sources of misinformation}

Politicisation of COVID-19

Misinformation was spread in several ways on Fijian social media, particularly 
towards the start of the pandemic. As early as February 2020, SODELPA MP Lynda Tabuya used her personal Facebook page to propagate allegations that the virus might be transported to Fiji by the southeast trade winds and that the government's intention to treat COVID-19 patients at Navua Hospital would put residents at danger (Singh, 2020). Fear and confusion spread fast on social media and messaging apps when the country's first case was detected in March 2020 and lockdowns were

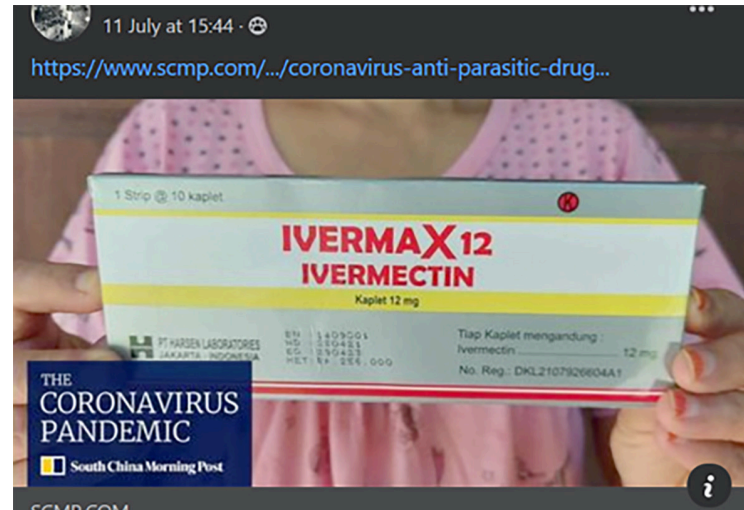

SCMP.COM

As Delta spreads in Asia, anti-parasitic drug ivermectin is hot property

Figure 3: Facebook post on Chat Fiji by a member sharing an article of the use of ivermectin in Indonesia, Malaysia and India against a variant of COVID-19. established in Lautoka, causing a surge of panic purchasing before authorities could respond (Radio New Zealand, 2020a). Tabuya was prosecuted, but later acquitted, under the Public Order Act on March 19 for comments she posted on Facebook encouraging residents to stock up on food.

During parliamentary sessions, misinformation and mal-information were used by some opposition party members to discredit the efforts of the Fiji health response by the government and supported right-wing evangelical claims of 'evil' that led to a global pandemic. One opposition member claimed that 'World evil group using China a Communist Dictatorial regime to invent or manufacture COVID-19 as a biological weapon against the West...' adding that what 'Fiji needs the most is Israel' (Nanuqa, 2020). The opposition MP also claimed that 'satanic forces' were involved. Attacking the WHO, the MP alleged that the WHO had sided with China over the poor handling of the COVID-19 outbreak. The Chinese Embassy in Fiji condemned claims made by Bulanauca, saying they were taken from fake social media pages (Radio New Zealand, 2020).

\section{Online vilification of COVID positive patients}

Fear and misinformation on the internet have led to the abuse and vilification of many COVID-19 patients in Fiji. In the 24 hours after the first coronavirus case was confirmed in Fiji, the patient, whose name was widely circulated on social media was subject to widespread vilification. The online social stigma was increased by government officials who said the patient misled the contact tracers by providing incomplete information. During a national press conference on 25 March 2020, the Prime Minister stated that: 
As we know, our first patient was a flight attendant in Lautoka. According to his first statement, he only began showing symptoms a day before he was admitted to hospital. Our subsequent investigations revealed that unfortunately, we weren't given the full story. Witnesses tell us he had been showing symptoms, including coughing, days prior and that he failed to place himself in self-quarantine. So, our contact tracing had to be extended further back to identify even more people he may have contacted and get them into quarantine as well...For anyone out there still asking why we've had to shut down the Lautoka confined area, this case is exactly why. We knew there was a risk that our first patient may have spread the virus to others. That is why we did not hesitate in shutting down movement into and out of the Lautoka confined area. No one in and no one out. If we hadn't done so, this new patient could have traveled to other parts of Fiji, potentially exposing others and vastly complicating our contact tracing efforts. (Fiji Ministry of Health and Medical Services, 2020)

Personal information and disinformation about these patients swiftly circulated on Facebook and messaging apps, including rumours about their religious beliefs, sexual orientation and social networks (Susu, 2020). The online stigma drew sharp criticism from the Fiji NGO Coalition of Human Rights, which called on national officials, the media and the public to exercise restraint and refrain from violating rights to privacy of COVID patients by publicly releasing personal information:

The emotional violence and fear that they have already subjected the index patient to is unprecedented - no other country affected by COVID-19 has demonised, humiliated and dehumanised its index patient the way this country has. We cannot talk about respecting the privacy of patients and eliminating violence against women and girls and yet perpetrating violence on the index patient by way of victim-blaming on national television and print media in the same breath. This is hypocritical. These dehumanising acts need to STOP as it has not only deeply affected the index patient, but also his family. (Fiji Women's Rights Movement, 2020)

While Fiji's international borders remained closed, the government allowed reparation of flights into the country. There are multiple anecdotes concerning sightings of supposed repatriated citizens not conforming to quarantine guidelines. This subsequently resulted in increasing anxiety. One such highly publicised case was that of a repatriated Fijian national (Patient 9) who breached self-quarantine orders upon his return from India. Despite testing positive for COVID-19, the patient travelled from Nadi to Suva and then to Labasa via an inter-island ferry, raising concerns and suspicions from people on Facebook (Figure 4). As a result, his family members in Suva contracted the virus and there were concerns of an outbreak on Vanua Levu (Fiji's second largest island). Upon his recovery, he was 


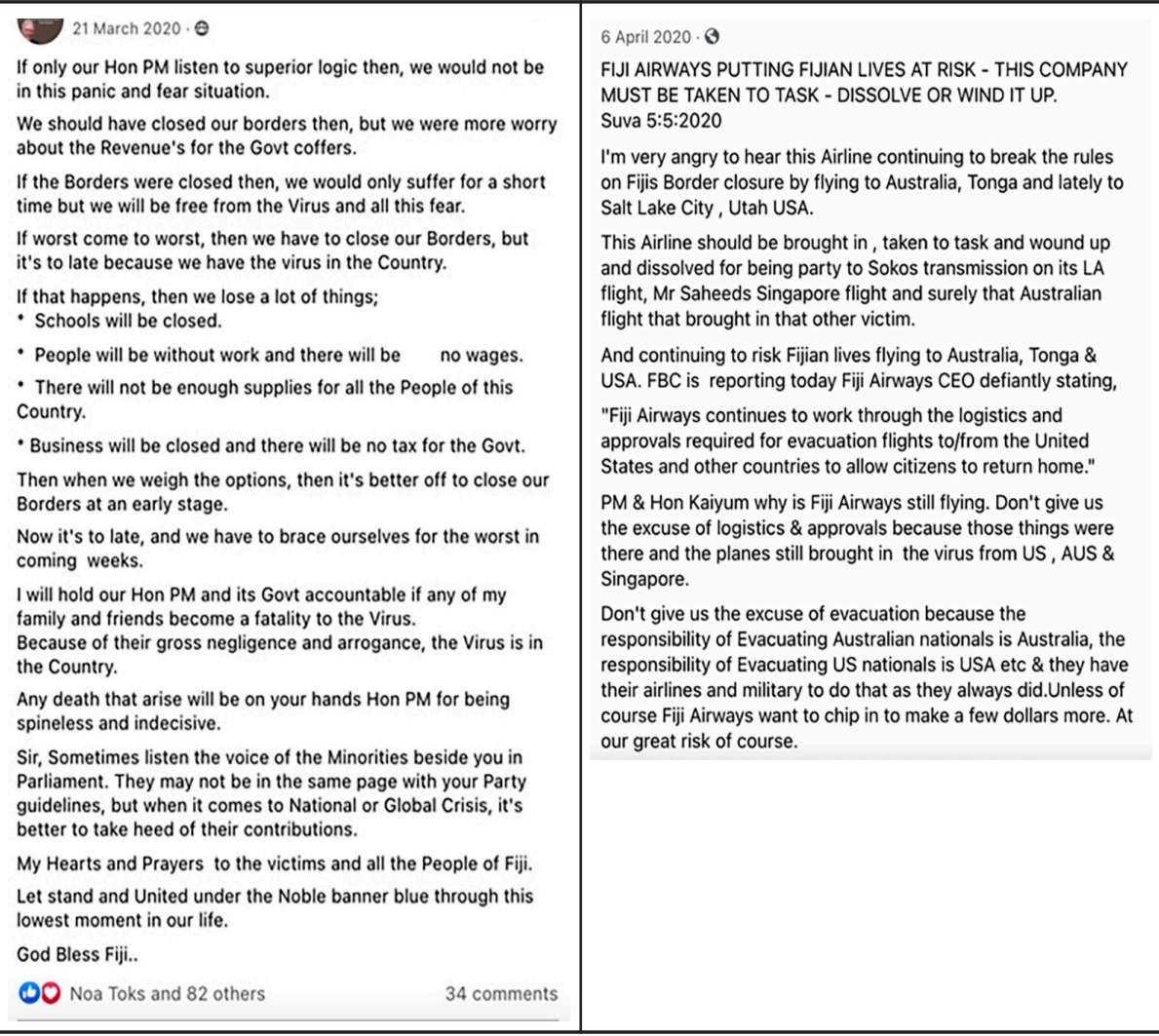

\section{Figure 4: A selection of Facebook posts on Chat Fiji by members on border closure and repatriation flights}

charged by the Fiji Police with one count of failing to comply with orders (Radio New Zealand, 2020a).

\section{Creation of the Stop 5G in Fiji Facebook Group: Dead birds, 5G and COVID-19}

International conspiracy theories regarding COVID-19 were also imported, modified, and reconstructed to match local circumstances in Fiji thanks to social media. The notion that 5G mobile broadband technology and the COVID-19 virus are somehow related is perhaps the most prominent of these conspiracy theories. Following a global trend of anti-5G sentiments, a new Facebook group, Stop 5G in Fiji, was created in April 2020 to mobilise popular support to convince the Fijian Government to stop the $5 \mathrm{G}$ network from being rolled out in Fiji. Over the course of the year, the group changed its name numerous times, most likely to capitalise on current topics and expand its membership, which had surpassed 14,000 by the end of 2020 .

Although Fiji has been spared more organised offline anti-5G protests, one case highlights the localisation of the $5 \mathrm{G}$ conspiracy theory that garnered 
the attention of the Fijian Government. On 6 April 2020, photos and videos of dead mynah birds in Savusavu appeared on both Chat (Fiji) and Stop 5G in Fiji Facebook groups. By Fiji standards, these posts went viral, with hundreds of shares, likes and comments (Fiji Sun, 2020). These posts attributed the death of the birds to $5 \mathrm{G}$, which is yet to be introduced to Fiji. As a result of local pictures of dead birds, more posts started appearing on Stop 5G in Fiji group, which were similar to stories of dead birds in the Netherlands, UK, Germany, and Italy. Following the online hysteria caused by the pictures of dead mynah birds, officials from the Department of Environment and Biosecurity Authority of Fiji were sent to Savusavu to investigate this (Fiji Sun, 2020). In a statement, the Minister for Agriculture said a post-mortem had concluded that the deaths of the mynah birds were due to blunt trauma, denying that the death of the birds stemmed from COVID-19 and the 5G Network as speculated on Facebook (The Fiji Times, 2020). Reuters also fact-checked multiple posts of dead birds in Europe that was circulated via social media as false and misleading, saying the pictures were from 2018 and that there were no links between the death of the birds and 5G or coronavirus (Reuters, 2020).

\section{Prevalence of international conspiracy theories on Fijian Facebook} 5 G Conspiracy Theory

Meese, Frith, \& Wilken (2020) identified two types of conspiracy theory linking $5 \mathrm{G}$ and COVID-19. The the first one insinuates that radiation from $5 \mathrm{G}$ lowers people's immune systems, making them more vulnerable to the virus. The second and more prominent conspiracy claims that 5G directly causes COVID-19. There are some variations around this conspiracy theory. Among the more notable of them are the erroneous claims that COVID-19 is a made-up pandemic to cover up the deleterious effects of $5 \mathrm{G}$ radiation (Hamilton, 2020) and that COVID-19 emerged from Wuhan because it had 'been the guinea-pig city for 5G' (Adams, 2020). Even more fantastic versions of this theory claimed that the pandemic was 'engineered by [. . .] Bill Gates, to depopulate an overcrowded planet' (Sorkin, 2020) (Wilson, 2020).

Both Chat (Fiji) and Fijian for a Safer \& Prosperous Fiji carried aspects of these conspiracy theories. One of the first posts to be shared on Chat (Fiji) was an article in early February, claiming that Wuhan in China rolled out $5 \mathrm{G}$ networks and links and citing what purported to be an open letter from ' 180 scientists and physicians' warning of the dangers of $5 \mathrm{G}$ technology (including 'flu-like symptoms). Two other links were shared that claimed that 'Wuhan was the province where $5 \mathrm{G}$ was rolled out, now the centre of deadly virus'. In their research, Bruns, Harrington, \& Hurcombe (2020) reveal that this was the first English-language post outlining the 5G-COVID links that were circulated widely via Facebook. Two of the popular posts that appeared on Chat (Fiji) were: 
China launched its 5G national network, the world's largest, around November 2019. One of the main 5G wireless connections was installed in Wuhan hospital, where all equipment is connected wirelessly. The same city where the outbreak of covid19 started. Some big countries like Italy, Spain, the USA, U.K. etc just recently rolled out 5 G mostly on public places like Airports, Hospitals, Cities, Stadiums now have the most numbers of covid19 cases. (Facebook post, February 21, 2020)

They [China] will deny it to safeguard their agenda and interests. Hubei Province in which Wuhan is situated was the testing field for 5G....most other countries affected have $5 \mathrm{G}$... So certainly logic plays an important part here. (Facebook post, March 3, 2020)

\section{Linking Bill Gates with the transmission of coronavirus}

Many people believe the theory that Bill Gates is one of the strategists behind COVID-19 and that his intention is to make money from the production and distribution of its vaccine. Some posts emerged in late February and early March claiming that the coronavirus is only the pretext for distributing a deadly vaccine which will be activated by $5 \mathrm{G}$ radiation and will lead to a mass depopulation of Earth at the behest of an obscure group that included Bill Gates (and the Gates Foundation). Two YouTube videos accompanied these posts, 'Bill Gates calls for Global Depopulation' and 'Bill Gates-Microchip vaccine implants to fight coronavirus'. These two videos have subsequently been removed from YouTube for violating community standards and spreading fake news. Further links are made with international organisations (such as the WHO and the UN), multinational technology firms like Huawei and prominent people like Bill Gates and George Soros, who are supposedly its backers. Some posts even link the 5G-Coronavirus conspiracy to the Freemasons and the Illuminati, who are supposedly trying to create a one-world government:

Another reason why Bill Gates openly supports and fund abortion clinics around the world... To terminate pregnancies and harvest baby body parts. Just so you know, he funds two research labs in Wuhan, the epicentre of the Corona virus pandemic. (Facebook post, March 13, 2020) (Staver, 2020)

One World Order - (Bill and Melinda Gates Foundation) setting up public-private partnerships with pharmaceutical companies to promoting certain sorts of corporate farming and the use of biotechnology for health and agriculture. (Facebook post, February 28, 2020)

An analysis of some of the most popular and prominent posts on the Stop 5G in Fiji Facebook Group reveal further exaggeration of the COVID/5G rumours, repeatedly pushed by the pre-existing obsessions of the various international conspiracy groups. Some continued to focus centrally on the supposed ill effects of $5 \mathrm{G}$ radiation with popular posts such as this: 
People say no to $5 \mathrm{G}$ otherwise will get brain tumour or cancer down the line say a few years from now. This high frequency of 5G once up it will be up 24/7 a week, all day/night and they have to place closer or shorter height like rooftops since its wave frequency abilities is shorter wave compare to $4 \mathrm{G}$ or $3 \mathrm{G}$ which can operate from a tower with a long distance wave $5 \mathrm{G}$ operates better closer to the ground, meaning closer to humans. Meaning humans will be exposed to radiation 27/4 which can cause cancer. (Facebook post, March 23, 2020)

Other posts in the Stop 5G in Fiji Facebook group asserted that COVID-19 was only a cover story to explain the effects of the $5 \mathrm{G}$ tests in Wuhan. Three posts (with links from obscure US sites) drew a connection between $5 \mathrm{G}$ to a much more convoluted theory involving bioengineering of COVID-19 with 5G activated vaccines (Figure 5):

The vaccine to cure its devastating impact is the chip they'll implant in your right hand or head- Satan. There is a better Cure-Jesus. Implant Him in your heart and He will surely get you through. (Facebook post, March $31,2020)$

Another popular post on the Stop 5G in Fiji group was a video by the notorious conspiracy theorist David Icke, who claimed that COVID-19 was a scam and that the illness was caused by $5 \mathrm{G}$ technology. While YouTube eventually took it down, the post was shared more than 103 times, garnering

\#CoronavirusIsABiologicalWeapon

I believe Coronavirus is a Biological Weapon engineered to wipe out a population. Something must have gone wrong in this HighTech Laboratory in Wuhan-China. This laboratory was recently opened in 2018 for the purpose of research to study the world's dangerous pathogens. They have brought in various types of human life deadly virus for the purpose of research that included SARS and others. USA have warned them when this lab was opened in 2018 and now we seeing the effects. China will never tell the truth. We need international community like World Health Organisation and the United Nation to investigate this Wuhan High-Teck Laboratory

\#GOD_BLESS_FIJI

dै

(1) 릉 45

14 comments

Figure 5: Facebook post on Chat Fiji, March 6, 2020. \#CoronavirusIsABiologicalWeapon some very intense discussions in the group with some apocalyptic Christian themes (Figure 6) and claims that COVID-19 and 5G were being used to bring about a mass vaccination that would allow the population to be controlled by the Illuminati and the Freemasons.

Other videos by or featuring David Ickes were shared both on Chat (Fiji) and Stop 5G in Fiji's Facebook groups: 'How People Are Controlled With This Pandemic Crisis_-David Icke Predicted The Future' and 'All Humans Will be microchipped be the year 2030'.

\section{Anti-China sentiments}

The idea that the coronavirus was developed in a laboratory in China is wide- 
spread on Facebook. This post is from Chat (Fiji) on February 22, 2020:

The Chinese lab (conspiracy) theory is there a high-level bio lab in Wuhan; Would anyone really be surprised that a Chinese lab mishandled and mistakenly released the virus? and everyone knows China would not admit to this anyway. The Wuhan disease lab is the focus of suspicion and conspiracy theories about covid-19's origins.

There were several Facebook posts on Chat (Fiji) of hate-speech and antiChinese views related to the COVID-19 pandemic and the origin of the coronavirus disease. One post suggested the sole responsibility for the outbreak lay with China (Figure 7) and that the country should cover losses and damage suffered by the rest of the world:

Let China be responsible for the deaths of all who died from covid-19. The responsible Government of China must make up for the loss of many lives around the world.

\section{Discussion}

Fijian officials declared the country free of community transmission of COVID-19 on 5 June 2020, after the final verified patient was released. Since that declaration, all COVID cases have been border quarantine cases involving people returning to Fiji. Fiji's COVID 19 responses by the Ministry of Health and Medical Services (MOHMS) have been effective in clarifying misinformation related to the pandemic during the outbreak in 2020. Data showed that many Fijians
666 is here already. Let's Pray Hard: 666 The Mark Of The Beast Prophesy Finally Fulfilled... The US Senate has passed the Obama Health Bill into law. The implementation would commence soon. This bill would require all Americans to be implanted with a Radio Frequency Identification (RFID) chip in order to access medical care. The device will be implemented on the forehead or on the arm. This is to fulfill the prophesy in the Book of Revelation 13:15-18 concerning the MARK OF THE BEAST. Are you still doubting the END TIME? Do u know that the special car which was made for Obama is known as the BEAST? Get READY. The rapture is near! Revelations 13 is being played out right before us. Many are still unaware. 1.

Why is the chip being implanted exactly where the Bible
it would be. Why On the hand and forehead. Why not anywhere else? 2. Why is being connected to your bank account? Remember the Bible says you won't be able to buy or sell without the mark 666 . And guess what! The chip is connected to your financial details. What breaks my heart the most is that many people in the church will not make it if Jesus comes now? Many are unaware that the ends is near. Don't tell me that its advancement in technology or never miss hell...think about it. Hell is not a pretty place, the worst part is that it is for eternity... He who has ears, let him hear what the Spirit says to the church. Please rather than post and forward senseless messages. Send to everyone you know. Do the work of an evangelist. Have you ever wondered what should have happened if we treat the Holy Bible the way we treat our mobile phone? And we really can't live without it. Only $7 \%$ percent will re-send this message. Don't be of the $93 \%$ who will not share the message. Satan said. "I wonder how humans claim to LOVE GOD and disobey Him, and claim send now.

Figure 6: Facebook post on Chat Fiji on April 5, 2020: Satan fulfils his promise!" LORD SAVE US! word repent and be converted. If you miss heaven you can 


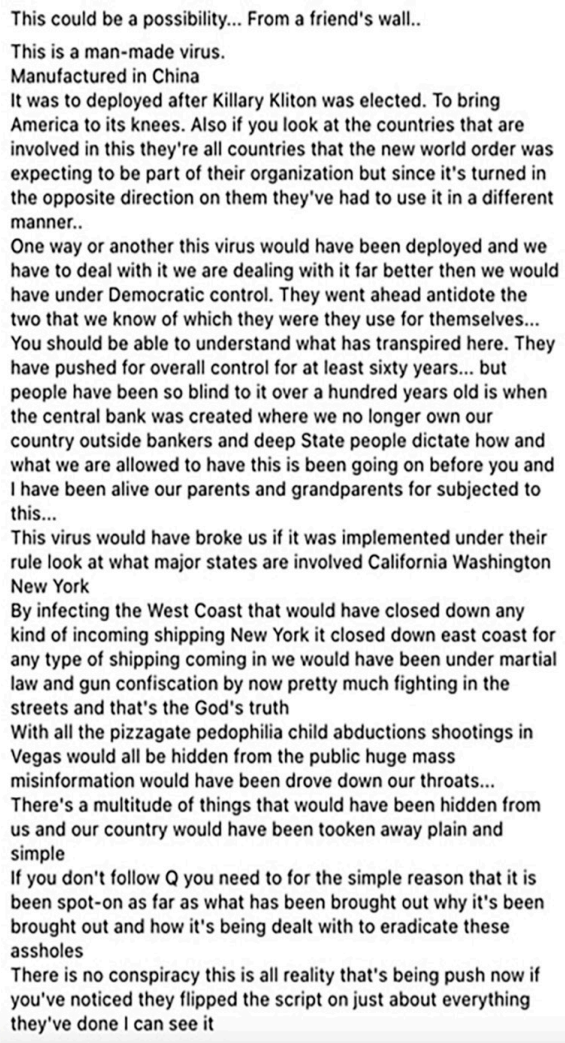

This virus would have broke us if it was implemented under their rule look at what major states are involved California Washington New York

By infecting the West Coast that would have closed down any kind of incoming shipping New York it closed down east coast for any type of shipping coming in we would have been under martial law and gun confiscation by now pretty much fighting in the streets and that's the God's truth

With all the pizzagate pedophilia child abductions shootings in Vegas would all be hidden from the public huge mass misinformation would have been drove down our throats...

There's a multitude of things that would have been hidden from us and our country would have been tooken away plain and simple

If you don't follow $Q$ you need to for the simple reason that it is been spot-on as far as what has been brought out why it's been brought out and how it's being dealt with to eradicate these assholes

There is no conspiracy this is all reality that's being push now if you've noticed they flipped the script on just about everything they've done I can see it

\section{Figure 7: A sample of Anti-China Facebook posts on Chat (Fiji)}

relied on news and information updates released through the Fiji MOHMS website (Kant, Leanne, \& Cain, 2021). Public health messages to promote awareness of COVID-19, as well as preventative measures such as social distance and handwashing, were part of the Fijian Government's response. Fiji, like many other countries, implemented travel restrictions and a 14-day quarantine period for international visitors. A prohibition on social gatherings, the closure of schools, institutions of religion, nightclubs, theaters, gyms, and swimming pools, as well as a national curfew were implemented in the affected districts.

Apart from demystifying fake news through official channels, authorities in Fiji also charged critics and 'rumor mongers' under the Public Order Act. Eight people were detained for 'spreading bogus news or claims to cause public anxiety' regarding COVID-19, including Opposition MP Lynda Tabuya. On March 26, Tabuya was arrested for allegedly violating the POA with Facebook posts about COVID-19. She was held for four days and charged with one count of malicious act contrary to the POA when she appeared in court on March 30. The prosecution dropped the accusations against her on August 17, and the matter was closed. 
Three women were arrested on March 26 for their Facebook posts about the virus; Nemani Bainivalu, a former Fiji First Party candidate, was arrested on March 27 and released on bail two days later; and a 24-year-old female radio announcer from Fiji Broadcasting was charged on April 11 with one count of a malicious act for social media posts that called on individuals 'to stone vehicles during curfew hours' (Talei, 2020; Fiji Sun Online, 2020; Kumar, 2020; Tadulala, 2020)

Many Christian denominations issued statements to their members to ensure that accurate and reliable information related to the COVID-19 pandemic was being sourced for self-edification. The Methodist Church, the largest denomination in Fiji, joined efforts to ensure responsible public awareness regarding the COVID-19 disease (Boila, 2020). While such attempts by religious bodies played an important part in the national response to misinformation and civil doubts, data shows that social media was still able to spread conspiracy theories and conflate mal-information to cast doubts on medical facts of the COVID-19 disease and its origins.

Research by the Asia Foundation found that despite the presence of misinformation on COVID-19 in Fiji, only 6 percent of the respondents believed it to be a hoax (Kant, Leanne, \& Cain, 2021). More than nine out of 10 people felt confidence in official sources of information even though two out of three people regularly came across some sort of misinformation on their social media platform. (Kant, Leanne, \& Cain, 2021)

When demand for verified information exceeded supply, such as when the first few domestic cases were detected, speculation and panic escalated, as they had in other countries. Conspiracy theory-focused online communities offered a more subtle and insidious threat. Anti-5G groups are a good example of this, because they often conflated their own claims with stories about COVID-19 vaccinations. Official messages and denials were used by the Fijian government to refute these notions, with varied results. Official sources refuting anti-5G ideas were frequently disregarded by anti-5G activists as merely another element of a larger conspiracy or as confirmation of their views in the government's ineptitude. According to the Asia Foundation research results, around 35 percent of the general community believe that 'avoiding mobile phone towers can keep one safe from COVID-19'. This idea is less widespread among those with higher levels of education (Kant, Leanne, \& Cain, 2021).

Following the declaration of Fiji as COVID-free and later as COVIDcontained (due to cases detected at the border), there was a noticeable change in discussions on Facebook and the intensity of fake news decreased drastically. The Stop 5G in Fiji group subsequently changed its name several times, most likely to capitalise on other issues.

Conspiracy is inclined to presume that notable public occasions are secretly arranged by influential and spiteful persons or organisations for certain gain (Douglas, et al., 2019). There were many Facebook posts relating the 5G mobile 
network to breeding coronavirus. There is also the trend of tweets that this virus is only spread in countries with $5 \mathrm{G}$ mobile networks, which brought violence against telecommunication engineers and property. Jolley and Paterson (2020) also attested to the fact that this conspiracy of 5G and COVID-19 would breed anger, violence, and paranoia. Allington, Duffy, Wessely, Dhavan, and Rubin (2020) concluded that social media is one of the carriers of conspiracy beliefs, which can only prevent health-protective behaviours.

\section{Conclusion}

This study capitalises on social media, a discursive space in which individuals with or without experience of COVID-19 shared information and their perspectives of the disease. In alignment with our study objective, we have been able to identify and analyse different themes about the pandemic during the initial stages of the outbreak in Fiji in 2020. Social media has become a wider part of people's lives and has a significant impact on decisions in people's lives; it is important to research its influence on people and health during this pandemic. As Fiji is in the throes of a more severe and widespread second wave of the virus coupled with a nation-wide vaccine rollout, some of the conspiracy theories have been reignited on Fijian Facebook forums with serious implications for government efforts at containing the virus. Vaccine hesitancy is on the rise with social media in Fiji aflush with misinformation and fake news.

As the global COVID-19 pandemic continues to challenge societies across the globe severely and as access to accurate information both about the virus itself and what lies in store for our communities continues to be limited, the generation of rumors and conspiracy theories with some explanatory value will continue unabated. The social media conversations have focused on four main conspiracy theories:

The relationship of the virus to the $5 \mathrm{G}$ network and Bill Gates's alleged role in a global vaccination project aimed at limiting population growth; a coverup perpetrated by the Chinese Communist Party after the virus leapt to human populations based largely on Chinese culinary practices; the release, either accidental or deliberate of the virus from, alternately, a Chinese laboratory or an unspecified military laboratory and its role as a bio-weapon.

This study makes an important contribution by performing a thematic analysis of the opinion of people on social media about COVID-19. It also raises a concern over the number of digital spaces that generate and distribute misinformation that is readily and easily accessible. For example, a good number of Facebook posts conflated conspiracy theories associating technology and laboratories to the novel virus and claimed that COVID-19 was part of a strategy conceived by Bill Gates to make money from selling vaccines.

In conclusion, misinformation fuelled by rumours, stigma and conspiracy 
theories can have potentially severe implications on public health if prioritised over scientific guidelines. Governments and other agencies must understand the patterns of COVID-19-related rumours, stigma, and conspiracy theories circulating so that they can develop appropriate risk communication messages.

\section{References}

ABC News. (2020, March 17). Australia accused of ignoring Pacific neighbours in face of COVID-19 outbreak. Retrieved August 4, 2020, from ABC News: https://www. abc.net.au/news/2020-03-17/coronavirus-australia-in-the-pacific-amid-the-covid19-outbreak/12060108

Abroms, L., Westmaas, J. L., \& J. Bontemps-Jones, R. R. (2013). A content analysis of popular smartphone apps for smoking cessation. American Journal of Preventive Medicine, 45(6), 732-736. https://doi.org/10.1016/j.amepre.2013.07.008

Adams, T. (2020, April 26). 5G, coronavirus and contagious superstition. The Guardian. Retrieved on August 22, 2020, from https:/www.theguardian.com/world/2020/ apr/26/5g-coronavirus-and-contagious-superstition

Ahmed, W., Vidal-Alaball, J., Downing, J., \& Seguí, F. L. (2020). COVID-19 and the $5 \mathrm{G}$ conspiracy theory: Social network analysis of twitter data. Journal of Medical Internet Research, 22(5), e19458. https://doi.org/10.2196/19458

Allington, D., Duffy, B., Wessely, S., Dhavan, N., \& Rubin, J. (2020). Health-Protective behaviour, social media usage and conspiracy belief during during the COVID-19 public health emergency. Psychological Medicine. 51(10), 1763-1769. https://doi. org/10.1017/S003329172000224X

Australian Department of Health. (2020, January 25). First confirmed case of novel coronavirus in Australia. Retrieved on August 18, 2020, from https://www.health.gov. $\mathrm{au} /$ ministers/the-hon-greg-hunt-mp/media/first-confirmed-case-of-novel-coronavirusin-australia

Boila, S. (2020, March 23). Church urges members not to spread misinformation. FBC News. Retrieved on January 30, 2021, from https://www.fbcnews.com.fj/news/covid-19/church-urges-members-not-to-spread-misinformation/

Bora, L., Das, D., Barman, B., \& Borah, P. (2018). Are internet videos useful sources of information during global public health emergencies? A case study of YouTube videos during the 2015-16 Zika virus pandemic. Pathogens and Global Health, 112(6), 320-328. https://doi.org/10.1080/20477724.2018.1507784

Brimacombe, T., Kant, R., Finau, G., Tarai, J., \& Titifanue, J. (2018). A new frontier in digital activism: An exploration of digital feminism in Fiji. Asia and the Pacific Policy Studies 5, 508-521. https://doi.org/10.1002/app5.253

Broniatowski, D. A., Jamison, A. M., Qi, S., AlKulaib, L., Chen, T., Benton, A., Dredze, M. (2018). Weaponized health communication: Twitter bots and Russian trolls amplify the vaccine debate. American Journal of Public Health, 108, 1378-1384. https://doi. org/10.2105/AJPH.2018.304567

Bruns, A., Harrington, S., \& Hurcombe, E. (2020). 'Corona? 5G? or both?': the dynamics of COVID-19/5G conspiracy theories on Facebook. Media International Australia, 117(1), p. 12-29. Retrieved from https://doi.org/10.1177/1329878X20946113

Buchanan, R., \& Beckett, R. D. (2014). Assessment of vaccination-related information for consumers available on Facebook. Health Information and Libraries Journal, 31(3), 227-234. https://doi.org/10.1111/hir.12073 
Cave, D. (2012). Digital islands: How the Pacific's ICT revolution is transforming the region. Lowy Institute. Retrieved on April 23, 2021, from www.lowyinstitute.org/publications/digital-islands-how-pacifics-ict-revolution-transforming-region

Chaslot, G. (2017). How YouTube's AI boosts alternative facts: YouTube's recommendation A.I. is designed to maximize the time users spend online. Fiction often outperforms reality. Medium.com. Retrieved on August 12, 2020, from https://medium. com/@guillaumechaslot/how-youtubes-a-i-boosts-alternative-facts-3cc276f47cf7

Chew, C., \& Eysenbach, G. (2010). Pandemics in the age of twitter: content analysis of tweets during the 2009 H1N1 outbreak. PLoS One, 5(11), e14118. https://doi. org/10.1371/journal.pone.0014118

Datta, S., O’Connor, P., Jankovic, D., Muscat, M., Mamou, M. B., Singh, S., \& Butler, R. (2018). Progress and challenges in measles and rubella elimination in the WHO European Region. Vaccine, 36(36), 5408-5415.

Douglas, K., Uscinski, J., Sutton, R., Cichocka, A., Nefes, T., Ang, C. S., \& Deravi, F. (2019). Understanding Conspiracy Theories. Political Psychology, 40, 3-35. https:// doi.org/10.1111/pops. 12568

Fiji Ministry of Health and Medical Services (2020, March 25). Statement by the Prime Minister Hon. Voreqe Bainimarama on Fifth COVID-19 case in Fiji. Retrieved March 30, 2021, from https://www.health.gov.fj/statement-by-the-prime-minister-honvoreqe-bainimarama-on-fifth-covid-19-case-in-fiji/

Fiji Ministry of Health and Medical Services (2021, July 19). COVID-19 update 2903-2021. Retrieved August 20, 2021, from https://www.health.gov.fj/19-07-2021/

Fiji Sun Online (2020, March 26). 3 To appear in court for positing false information on social media. Retrieved from https://fijisun.com.fj/2020/03/26/3-to-appear-in-courtfor-positing-false-information-on-social-media/

Fiji Sun (2020a, April 15). Bird deaths caused by blunt trauma. Retrieved on August 3, 2020, from https://fijisun.com.fj/2020/04/15/bird-deaths-caused-by-blunttrauma/\#: :text=The $\% 20$ Ministry $\% 20$ of $\% 20$ Agriculture $\% 20 \mathrm{in}, 19 \% 20$ and $\% 20$ the $\% 205 \mathrm{G} \% 20$ Network.\&text=Causes $\% 20$ of $\% 20$ death $\% 20$ appearing $\% 20$ to $\% 20$ be $\% 20$ blunt $\% 20$ trauma.

Fiji Sun (2020b, April 9). Ministry of Agriculture probes dead birds mystery in Naweni. Retrieved on August 4, 2020, from https://fijisun.com.fj/2020/04/09/minstry-ofagriculture-probes-dead-birds-mystery-in-naweni/

Fiji Times. (2020, April 15). Post-mortem exam results reveal why mynah birds died in Savusavu. Retrieved on August 3, 2020, from https://www.fijitimes.com/postmortem-exam-results-reveal-why-mynah-birds-died-in-savusavu/

Fiji Women's Rights Movement. (2020, March 30). Stop victim-blaming of COVID-19 patients. NGOCHR and Rainbow Pride Foundation. Retrieved on August 3, 2020, from http://www.fwrm.org.fj/news/media-releases/67-all-category/news/press-releases/571ngochr-and-rainbow-pride-foundation-stop-victim-blaming-covid-19-patients

Finau, G., Prasad, A., Kant, R., Tarai, J., Logan, S., \& Cox, J. (2014). Social media and e-democracy in Fiji, Solomon Islands and Vanuatu. 20th Americas Conference on Information Systems. Association for Information Systems.

Finau, G., Cox, J., Tarai, J., Kant, R., Varea, R., \& Titifanue, J. (2018). Social media and disaster communication: A case study of Cyclone Winston. Pacific Journalism Review : Te Koakoa, 24(1), 123-137. https://doi.org/10.24135/pjr.v24i1.400

Franz, D., Marsh, H. E., Chen, J. I., \& Teo, A. R. (2019). Using Facebook for qualitative research: A brief primer. Journal of Medical Internet Research, 21(8), e13544. https://doi.org/10.2196/13544 
Free, C., Phillips, G., Galli, L., Watson, L., Felix, L., Edwards, P., \& Haines, A. (2013). The effectiveness of mobile-health technology-based health behaviour change or disease management interventions for health care consumers: a systematic review. PLOS Medicine, 10(1), e1001362. https://doi.org/10.1371/journal.pmed.1001362.

Glaser, B., \& Strauss, A. (1967). The discovery of grounded theory: Strategies for qualitative research. Chicago, IL: Aldine.

Hamilton, I. A. (2020, April 6). Here's what we know about the bizarre coronavirus 5G conspiracy theory that is leading people to set mobile phone masts on fire. Business I nsider. Retrieved on August 22, 2020, from https://www.businessinsider.com.au/ coronavirus-conspiracy-5g-masts-fire-2020-4? $\mathrm{r}=\mathrm{US} \& \mathrm{IR}=\mathrm{T}$

He, Z., Cai, Z., \& Wang, X. (2015). Modeling propagation dynamics and developing optimized countermeasures for rumor spreading in online social networks. 2015 IEEE 35 th International Conference on Distributed Computing Systems.

Hooper, Val. 2020. Misinformation in the 2019 Samoan measles epidemic: The role of the influencer. Proceedings of the Seventh European Conference on Social Media (pp. 112-118). UCLan, Larnaka, Cyprus.

Jolley, D., \& Paterson, L. (2020). Pylons ablaze: Examining the role of 5G COVID-19 conspiracy beliefs and support for violence. British Journal of Social Psychology, 59, 628-640. https://doi.org/10.1111/bjso.12394

Kant, R., Jorari, L., \& Cain, T. N. (2021). COVID-19 awareness, online discussion and vaccine distribution in Melanesia: Evidence and analysis from Fiji, Papua New Guinea, and Vanuatu. San Francisco, CA: The Asia Foundation.

Kemp, S. (2021, February 11). Digital 2021: Fiji. Data portal. Retrieved on February 26, 2021, from https://datareportal.com/reports/digital-2021-fiji

Kouzy, R., Jaoude, J. A., Kraitem, A., Alam, M. B., Karam, B., Adib, E., Baddou, K. (2020). Coronavirus goes viral: Quantifying the COVID-19 misinformation Epidemic on Twitter. Cureus, 12(3), e7255. https://doi.org/10.7759/cureus.7255

Kumar, A. (2020, August 17). SODELPA MP Lynda Tabuya acquitted. Fiji Sun Online. Retrieved from https://fijisun.com.fj/2020/08/17/sodelpa-mp-lynda-tabuya-acquitted/

Lazer, D., Baum, M., Benkler, Y., Berinsky, A., Greenhill, K., Menczer, F., \& Zittrain, J. (2018). The science of fake news. Science, 359(6380), 1094-1096. https://doi. org/10.1126/science.aao2998

Li, H. O.-Y., Bailey, A., Huynh, D., \& Chan, J. (2020). Youtube as a source of information on COVID-19: A pandemic of misinformation? BMJ Global Health, 5(e002604). https://doi.org/10.1136/bmjgh-2020-002604

Logan, S. (2012). Rausim!: Digital politics in Papua New Guinea. SSGM Discussion Paper, The Australian National University, 2012(9).

Meese, J., Frith, J., \& Wilken, R. (2020, August). COVID-19, 5G conspiracies and infrastructural futures. Media International Australia, 177(1), 30-46. https://doi. org/10.1177/1329878X20952165

Ministry of Health and Medical Services. (2021, March 29). COVID-19 Update 2903-2021. Retrieved March 30, 2021, from http:/www.health.gov.fj/covid-19-update-29-03-2021/

Nanuqa, J. (2020, July 27). Bulanauca says evil groups to blame for COVID-19. FBC News. Retrieved on January 30, 2021, from https://www.fbcnews.com.fj/news/parliament/bulanauca-says-evil-groups-to-blame-for-covid-19/

Ortiz-Martínez, Y., \& Jiménez-Arcia, L. (2017). Yellow fever outbreaks and Twitter: Rumours and misinformation. American Journal of Infection Control, 45, 815-816. https://doi.org/10.1016/j.ajic.2017.02.027 
Rabonu, I. (2020, March 11). Testing for coronavirus to be done locally at the new Fiji Centre For Disease Control. Fiji Sun. Retrieved on August 3, 2020, from https:// fijisun.com.fj/2020/03/11/testing-for-coronavirus-to-be-done-locally-at-the-new-fijicentre-for-disease-control/

Radio New Zealand. (2020a, May 29). Fiji COVID-19 patient charged with breaching quarantine orders. Retrieved from https://www.rnz.co.nz/international/pacificnews/417864/fiji-covid-19-patient-charged-with-breaching-quarantine-orders

Radio New Zealand. (2020b, July 31). China slams Fiji opposition's COVID-19 claims. Retrieved on January 29, 2021, from https://www.rnz.co.nz/international/pacificnews/422486/china-slams-fiji-opposition-s-covid-19-claims

Reuters. (2020, April 29). False claim: Pictures link bird deaths to new $5 \mathrm{G}$ mast in the Netherlands. Reuters. Retrieved on Augst 4, 2020, from https://www.reuters.com/ article/uk-factcheck-starlings-netherlands/false-claim-pictures-link-bird-deaths-tonew-5g-mast-in-the-netherlands-idUSKCN22A3D9

Ritterband, L., \& Tate, D. (2009). The science of internet interventions. Introduction. Annals of Behavioral Medicine, 38(1), 1-3.

Salathé, M., \& Khandelwal, S. (2011). Assessing vaccination sentiments with online social media: implications for infectious disease dynamics and control. PLOS Computational Biology, 7(10), e1002199. Retrieved from https://doi.org/10.1371/journal.pcbi.1002199

Scanfeld, D., Scanfeld, V., \& Larson, E. (2010). Dissemination of health information through social networks: twitter and antibiotics. American Journal of Infection Control, 38(3), 182-188. https://doi.org/10.1016/j.ajic.2009.11.004

Schreiber, R. S., \& Stern, P. N. (2001). The 'how to' of grounded theory: Avoiding the pitfalls. In R. S. Schreiber, \& P. N. Stern (Eds.), Using grounded theory in nursing (pp. 55-84). New York, NY: Springer.

Serrano, E., Iglesias, C., \& Garijo, M. (2015). A novel agent-based rumor spreading model in twitter. Proceedings of the 24th International Conference on World Wide Web.

Sorkin, A. D. (2020, April 24). The dangerous coronavirus conspiracy theories targeting $5 \mathrm{G}$ technology, Bill Gates, and a world of fear. The New Yorker. Retrieved on August 22, 2020, from https://www.newyorker.com/news/daily-comment/the-dangerous-coronavirus-conspiracy-theories-targeting-5g-technology-bill-gates-and-a-world-of-fear

Seyoum, M. (2019, July 15) Social media fuels the anti-vaxx movement. Now what? YR Media. Retrieved on April 2, 2020, from https://yr.media/tech/social-media-fuelsthe-anti-vaxx-movement-now-what.

Singh, I. (2020, February 20). Stop the misinformation about COVID 19 says Minister. Fiji Broadcasting Corporation. Retrieved on August 3, 2020, from https:/www.fbcnews.com.fj/news/parliament/stop-the-misinformation-about-covid19-says-minister/ Spyksma, H. (2017). Unintentional journalists: The role of advocacy group 350 in filling a news gap for reporting from the Pacific region. Journalism Studies, 20(1), 1-21. https://doi.org/10.1080/1461670X.2017.1351885

Steinhubl, S., Muse, E., \& Topol, E. (2015). The emerging field of mobile health. Science Translational Medicine, 7(283), 283rv3. https://doi.org/10.1126/scitranslmed.aaa3487

Susu, A. (2020, March 21). COVID-19: Ministry worried about vilification. Fiji Times. Retrieved from https://www.fijitimes.com/covid-19-ministry-worried-about-vilification/ Tadulala, K. (2020, March 28). Tabuya charged, Bainivalu remains in custody. FBC News. Retrieved from https://www.fbcnews.com.fj/news/tabuya-charged-bainivaluremains-in-custody/

Talei, F. (2020, June 13). Woman, 47, limited from posting on social media. Fiji Sun Online. Retrieved from https://fijisun.com.fj/2020/06/13/woman-47-limited-from- 
posting-on-social-media/

Tarai, J., Finau, G., Kant, R., \& Titifanue, J. (2015). Political social media campaigning in Fiji's 2014 elections. The Journal of Pacific Studies, 35(2), 89-114.

Titifanue, J., Kant, R., \& Finau, G. (2020). A crucible for bottom-up regionalism? The digital renaissance: West Papuan media suppression and social media in the Pacific. Pacific Journalism Review : Te Koakoa, 26(1), 140-147. https://doi.org/10.24135/ pjr.v26i1.1079

Titifanue, J., Tarai, J., Kant, R., \& Finau, G. (2015). From social networking to activism: The role of social media in the free West Papua campaign. Pacific Studies, 39(3), 255-281.

Wakamiya, S., Kawai, Y., \& Aramaki, E. (2016, October). After the boom no one tweets: Microblog-based influenza detection incorporating indirect information. EDB ' 16 : Proceedings of the Sixth International Conference on Emerging Databases: Technologies, Applications, and Theory (pp. 17-25).

Wang, Y., McKee, M., Torbica, A., \& Stuckler, D. (2019). Systematic literature review on the spread of health-related misinformation on social media. Social Science \& Medicine, 240, 112552. Retrieved from https://doi.org/10.1016/j.socscimed.2019.112552

Wardle, C. (2017, February 16). Fake news. It's complicated. First Draft. Retrieved August 12, 2020, from https://firstdraftnews.org/latest/fake-news-complicated/

Wardle, C., \& Derakhshan, H. (2017). Information disorder: Toward an interdisciplinary framework for research and policy making. Strasbourg, France: Council of Europe.

Wilson, C. (2020, May 11). Why are Australians chanting 'arrest Bill Gates' at protests? This wild Facebook group has the answers. Buzzfeed. Retrieved from August 22, 2020, from https:/www.buzzfeed.com/cameronwilson/lockdown-protest-australiabill-gates-conspiracy-theories

World Economic Forum. (2013). Global Risks 2013. Retrieved on August 22, 2020, from http://wef.ch/GJKqei

World Health Organisation. (2020, June 11). Defending the Pacific: Engaging communities to prepare for COVID-19. Retrieved on August 24, 2020, from https:/www. who.int/fiji/news/feature-stories/detail/defending-the-pacific\#: :text=American $\% 20$ Samoa $\% 2$ C $\% 20$ Cook $\% 20$ Islands $\% 2$ C $\% 20$ Kiribati,Futuna $\% 20$ are $\% 20$ still $\% 20$ virus $\% 2 \mathrm{Dfree}$

Zarocostas, J. (2020, February 29). How to fight an infodemic. The Lancelet, 395(10225), 676. https://doi.org/10.1

Romitesh Kant is an honorary associate in the Institute for Human Security and Social Change, La Trobe University, Melbourne, Australia.

romit.fj@gmail.com

Rufino Varea is a research associate in the School of Agriculture, Geography, Environment, Ocean and Natural Sciences, University of the South Pacific, Suva, Fiji. rvarea97@gmail.com 